\title{
OPTIMASI SABUN CAIR EKSTRAK ETANOL RIMPANG Zingiber officinale Rosc. var.rubrum DENGAN VARIASI MINYAK JARAK DAN KALIUM HIDROKSIDA
}

\author{
Nanda Paramita, Andhi Fahrurroji, Bambang Wijianto \\ Program Studi Farmasi Fakultas Kedokteran, Universitas Tanjungpura, Pontianak \\ Jalan Prof. Dr. H. Hadari Nawawi Pontianak \\ email: Freee_92@yahoo.co.id
}

\begin{abstract}
One of the causes of skin diseases are bacterial infections, such as Staphylococcus aureus and Staphylococcus epidermidis. Based on previous studies of red ginger (Zingiber officinale Rosc var.rubrum) have antibacterial activity. The aimed of this research was to find the optimum concentration of castor oil and potassium hydroxide (KOH) with good physicochemical properties with Simplex Lattice Design method, and determine the effectiveness of liquid soap against Staphylococcus aureus and Staphylococcus epidermidis with disc diffusion test. Extraction of red ginger with shoxletation and 96\% ethanol. The optimization liquid soap design was using Simplex Lattice Design. The basic liquid soap composition was used to predict the optimum formula contain castor oil and KOH for comparasion (0: 100), (25:75), (50:50), (75:25), (100: 0). The research showed optimum consentration value of red ginger ethanol extract is 5\%. The optimum formulas contained of 40,035 $\mathrm{g}$ of castor oil and 10,875 $\mathrm{g} \mathrm{KOH}$. The optimum liquid soap's colour was brown, charateristic smell of ginger, stiff, with a pH value of 9,4, viscosity of $1233 \mathrm{cP}$, $1,14 \%$ free fatty acids and alkali-free $0 \%$. The independent $T$ test result by using the $R$ 2.14.1 program was $p$ values $>0.05$ against $S$. epidermidis and $p<0.05$ against $S$. aureus. As conclusion, the Simplex Lattice Design can produce optimum liquid soap formulas and give antibacterial effectiveness.
\end{abstract}

Keywords: Castor Oil, KOH, Simplex Lattice Design, Red Ginger

\begin{abstract}
ABSTRAK
Penyebab terjadinya infeksi penyakit kulit adalah bakteri, seperti Staphylococcus aureus (S.aureus) dan Staphylococcus epidermidis (S.epidermidis). Berdasarkan penelitian sebelumnya jahe merah (zingiber officinale Rosc var.rubrum) memiliki aktivitas antibakteri. Tujuan dari penelitian ini adalah mengetahui konsentrasi optimum minyak jarak dan kalium hidroksida $(\mathrm{KOH})$ dengan memiliki sifat fisikokimia yang baik dengan metode Simplex Lattice Design, serta mengetahui efektivitas sabun cair terhadap S. aureus dan S.epidermidis dengan metode disc diffusion. Simplisia diekstraksi menggunakan sokletasi dengan pelarut etanol $96 \%$. Perancangan formula optimum sabun cair menggunakan metode Simplex Lattice Design. Rancangan formula awal untuk memprediksi formula optimum terdiri dari 5 formula dengan perbandingan minyak jarak dan $\mathrm{KOH}(0: 100),(25: 75),(50: 50),(75: 25),(100: 0)$. Berdasarkan pengujian aktivitas zat aktif diperoleh konsentrasi optimum yaitu 5\%. Rancangan formula sabun cair optimum terdiri dari 40,035 g minyak jarak dan 10,875 g KOH. Sabun cair optimum berwarna coklat, bau khas jahe, cairan kental, dengan nilai $\mathrm{pH} 9,4$, viskositas $1233 \mathrm{cP}$, asam lemak bebas $1,14 \%$ dan alkali bebas $0 \%$. Uji $\mathrm{T}$ independent dengan program $R-2141$ menghasilkan nilai $\mathrm{p}>0,05$ terhadap $S$. epidermidis dan $\mathrm{p}<0,05$ terhadap S.aureus. Hasil
\end{abstract}


penelitian menyimpulkan bahwa metode Simplex Lattice Design dapat menghasilkan formula sabun cair yang optimum dan memiliki efektivitas sebagai antibakteri.

Kata kunci: Minyak Jarak, KOH, Simplex Lattice Design, Rimpang Jahe Merah

\section{PENDAHULUAN}

Penyakit kulit merupakan salah satu penyakit yang masih menjadi masalah kesehatan masyarakat Indonesia. Hal tersebut didukung data dari Kemenkes Republik Indonesia tahun 2011, penyakit kulit dan jaringan subkutan tahun 2010 menduduki peringkat ketiga dengan jumlah penderita 122.076 orang (Kementrian Kesehatan Republik Indonesia, 2011). Faktor dominan yang paling berperan dalam penularan penyakit kulit adalah hygiene perorangan yang rendah sehingga menyebabkan infeksi bakteri, seperti Staphylococcus aureus (S.aureus) dan Staphylococcus epidermidis (S.epidermidis) yang merupakan bakteri yang paling dominan pada kulit manusia (Notobroto, dkk., 2005; Radji, 2010). Salah satu cara perorangan untuk terhindar dari penyakit kulit yaitu dengan menggunakan suatu produk kosmetik sebagai pembersih kulit seperti sabun mandi cair.

Permintaan sabun mandi cair cenderung meningkat dari tahun ke tahun. Hal ini dikarenakan sabun cair memiliki beberapa keunggulan, yaitu lebih higienis, praktis dan ekonomis bagi konsumen (Watkinson, 2000). Salah satu cara yang dilakukan untuk menciptakan formulasi sabun mandi cair yang optimum dengan memvariasikan minyak jarak dan alkali $(\mathrm{KOH})$ sebagai bahan dasar menggunakan metode Simplex Lattice Design.

Metode Simplex Lattice Design digunakan untuk menentukan proporsi relatif bahan-bahan yang dapat dikuantifikasi yang digunakan dalam formula sehingga menghasilkan suatu formula yang paling baik sesuai kriteria yang ditentukan (Kurniawan dan Sulaiman, 2009). Sears (2001) mengemukakan bahwa di dunia, produk sabun mandi berbasis bahan alam masih jarang ditemukan di pasaran . Bahan baku yang digunakan sebagai antibakteri salah satu nya adalah jahe merah.

Jahe merah (Zingiber officinale Rosc. var. Rubrum) adalah salah satu varietas jahe yang merupakan tanaman obat yang tumbuh di Indonesia. Senyawa metabolit sekunder suku Zingiberaceae dapat menghambat pertumbuhan bakteri $S$. aureus dan $S$. epidermidis. Berdasarkan penelitian yang telah dilakukan, ekstrak etanol rimpang jahe merah mempunyai senyawa golongan fenolik, flavonoid, terpenoida, tanin, steroid dan minyak atsiri yang diduga dapat menghambat pertumbuhan bakteri (Okigbo, dkk., 2009).

\section{METODE PENELITIAN}

\section{Alat}

Alat yang digunakan pada penelitian ini antara lain, vacuum rotary evaporator (Rotavapor II BUCHI), water bath (Memmert tipe WNB14), timbangan analitik (Precisa tipe XB 4200C dan BEL tipe M254Ai), oven (memmert Beschickung-Loading Model 100-800), krusibel porselen, desikator, corong kaca (Iwaki Pyrex), Biological Safety Cabinet (BSC) (ESCO class II tipe B2), laminar air flow (LAF) cabinet, autoklaf (HL 36Ae), Viskometer (Viskotester Brook field VT-03F), $\mathrm{pH}$ meter (Hanna Instruments HI98107), alat gelas (Iwaki Pyrex), jarum Ose, tip dan mikropipet (Acura), pembakar Bunsen.

\section{Bahan}

Penelitian ini menggunakan rimpang jahe merah (Zingiber officinale Rosc. var. rubrum), minyak jarak, $\mathrm{KOH}$, asam stearat, asam oleat, glyserin, BHT, akuades, Dettol (sebagai kontrol positif), etanol 96\% (Merck), spiritus, Media 
Mualler Hinton Agar (MHA) (Oxoid), Media Natrium Agar (NA) (Oxoid).

Bakteri uji yang digunakan pada penelitian ini antara lain kultur murni Staphylococcus aureus dan kultur murni Staphylococcus epidermidis yang merupakan koleksi dari Unit laboratorium Kesehatan (ULK) Pontianak.

\section{Ekstraksi Simplisia Rimpang Jahe Merah}

Serbuk simplisia rimpang jahe merah diekstraksi dengan pelarut etanol 96\% teknis secara sokletasi. Alat sokletasi dirangkai, sampel dibungkus dengan kertas saring dan dimasukkan ke sifon. Sokletasi dilakukan hingga pelarut yang melewati sifon tidak berwarna. Ekstrak yang diperoleh diuapkan di atas waterbath pada suhu $60^{\circ} \mathrm{C}$ (Malu, dkk., 2009; Kristanti, dkk., 2008).

\section{Skrining Fitokimia}

Skrining fitokimia meliputi uji alkaloid, terpenoid, fenol, flavonoid, saponin dan tannin (Kristanti, dkk., 2008; Robinson, 1983; Harbone, 1973).
Uji Aktivitas Ekstrak Jahe Merah dengan Metode Disc Diffusion (Tes Kirby-Bauer)

Pembuatan larutan ekstrak rimpang jahe merah terdiri dari pembuatan pembuatan variasi konsentrasi. Konsentrasi yang digunakan adalah 5\%, 10\% dan $20 \%$ yang dilarutkan dengan pelarut DMSO 15\% dan aquades ad $10 \mathrm{~mL}$. Masing-masing konsentrasi tersebut diujikan terhadap bakteri dengan cara, cakram kertas yang berukuran $6 \mathrm{~mm}$ diteteskan $20 \mu \mathrm{L}$ dalam larutan ekstrak rimpang jahe merah dengan variasi konsentrasi, kemudian ditempatkan diatas permukaan media sesuai dengan posisi yang diinginkan. Cawan petri diinkubasi pada suhu $37^{\circ} \mathrm{C}$ selama 24 jam kemudian diamati zona hambat yang terbentuk yang diinterpretasikan dengan melihat daerah bening di sekitar cakram yang menunjukkan tidak adanya pertumbuhan bakteri (Indian Council of Medical Research, 2009).

Pembuatan Sediaan Sabun Mandi Cair Rancangan formula sabun cair dapat dilihat pada Tabel 1.

Tabel 1. Variasi Konsentrasi Minyak Jarak dan $\mathrm{KOH}$

\begin{tabular}{|c|c|c|c|c|c|}
\hline \multirow{2}{*}{ Bahan } & \multicolumn{5}{|c|}{ Formulasi } \\
\hline & $\mathrm{F} 1$ & $\mathrm{~F} 2$ & F3 & $\mathrm{F} 4$ & F5 \\
\hline \multirow{2}{*}{$\begin{array}{l}\text { Ekstrak etanol rimpang jahe merah } \\
\mathrm{KOH}(\mathrm{g})\end{array}$} & \multicolumn{5}{|c|}{$5 \%$} \\
\hline & 8,15 & 6,65 & 5,15 & 3,65 & 2,15 \\
\hline \multirow{2}{*}{$\begin{array}{l}\text { Minyak Jarak (g) } \\
\text { Asam Stearat (g) }\end{array}$} & 25,79 & 27,29 & 28,79 & 30,29 & 31,79 \\
\hline & \multicolumn{5}{|c|}{3,5} \\
\hline Asam Oleat (mL) & \multicolumn{5}{|c|}{5} \\
\hline Gliserin $(\mathrm{mL})$ & \multicolumn{5}{|c|}{15} \\
\hline $\mathrm{BHT}(\%)$ & \multicolumn{5}{|c|}{0,1} \\
\hline Aquades (mL) & \multicolumn{5}{|c|}{ Ad 100} \\
\hline
\end{tabular}

Semua bahan ditimbang dengan seksama. Proses pembuatan sabun diawali dengan mereaksikan asam stearat dengan fase minyak dan $\mathrm{KOH}$. Asam stearat dilelehkan dengan pemanasan $\left(70^{\circ} \mathrm{C}\right)$ sampai mencair. Setelah asam stearat, asam oleat dan minyak jarak homogen kemudian ditambahkan $\mathrm{KOH}$ sedikit demi sedikit pada suhu $60-70^{\circ} \mathrm{C}$ diaduk homogen sehingga didapatkan sabun pasta. Pengadukan terus dilakukan sampai homogen kemudian dilakukan penambahan gliserin sehingga pengadukan lebih mudah dilakukan. Setelah larutan menjadi homogen selanjutnya ditambahkan BHT, ekstrak 
jahe merah dan aquades hingga $100 \mathrm{~mL}$ (Hernani, dkk., 2010).

\section{Pemeriksaan pH}

Pemeriksaan $\mathrm{pH}$ diawali dengan kalibrasi alat $\mathrm{pH}$ meter menggunakan larutan dapar $\mathrm{pH} 7$ dan $\mathrm{pH}$ 4. Satu gram sediaan yang akan diperiksa diencerkan dengan air suling hingga $10 \mathrm{~mL}$. Diambil sedikit sediaan dan ditempatkan pada tempat sampel $\mathrm{pH}$ meter, kemudian ditunggu hingga indikator $\mathrm{pH}$ meter stabil dan menunjukkan nilai $\mathrm{pH}$ yang konstan (Dewan Standarisasi Nasional, 1996) .

\section{Penentuan Alkali Bebas}

Penentuan alkali bebas dilakukan dengan cara sebagai berikut. Sabun cair ditimbang sebanyak $5 \mathrm{~g}$, dimasukkan ke dalam erlemeyer tutup asah $250 \mathrm{~mL}$. Ditambahkan $100 \mathrm{~mL}$ alkohol 96\% netral, batu didih serta beberapa tetes larutan indikator phenophtalein. Dipanaskan diatas penangas air memakai pendingin tegak selama 30 menit mendidih. Bila larutan berwarna merah, kemudian titer dengan larutan $\mathrm{HCl} 0,1 \mathrm{~N}$ dalam alkohol sampai warna merah tepat hilang (Dewan Standarisasi Nasional, 1996).

\section{Penentuan Asam Lemak Bebas}

Penentuan asam lemak bebas dilakukan dengan cara, ditimbang $5 \mathrm{~g}$ sabun cair, dimasukkan ke dalam erlemeyer tutup asah $250 \mathrm{~mL}$. Ditambahkan $100 \mathrm{~mL}$ alkohol 96\% netral, batu didih serta beberapa tetes larutan indikator phenophtalein. Dipanaskan diatas penangas air memakai pendingin tegak selama 30 menit mendidih. Bila larutan tidak berwarna merah, kemudian titer dengan larutan $\mathrm{KOH} \quad 0,1 \mathrm{~N}$ dalam alkohol sampai terbentuk warna merah (Dewan Standarisasi Nasional, 1996).

\section{Pemeriksaan Viskositas}

Rotor yang digunakan terlebih dahulu dipasang pada alat. Sampel dimasukkan ke dalam wadah kemudian rotor dimasukkan sampai tercelup. Alat dihidupkan dan diukur viskositasnya dengan cara membaca langsung pada skala.

\section{Penentuan Formula Sabun Cair Opimum}

Setelah dilakukan evaluasi sifat fisikokimia formula F1, F2, F3, F4 dan F5 selanjutnya dilakukan pengolahan data untuk memperoleh formula optimum.

\section{Uji Efektivitas Antibakteri Pada Sediaan Optimum dengan Metode Disc Diffusion (Tes Kirby-Bauer)}

Cakram kertas yang berukuran 6 $\mathrm{mm}$ ditempatkan diatas permukaan media sesuai dengan posisi yang diinginkan, kemudian diteteskan sabun cair ekstrak etanol rimpang jahe merah dengan variasi konsentrasi. Kontrol positif yang digunakan adalah sabun cair dettol, kemudian kontrol negatif yang digunakan adalah Dimethyl Sulfodioxide (DMSO) dan sabun cair tanpa ekstrak di atas kertas cakram steril. Cawan petri diinkubasi pada suhu $37^{\circ} \mathrm{C}$ selama 24 jam kemudian diamati zona hambat yang terbentuk yang diinterpretasikan dengan melihat daerah bening disekitar cakram yang menunjukkan tidak adanya pertumbuhan bakteri (Indian Council of Medical Research, 2009).

\section{Analisa Data}

Analisa menggunakan uji statistika dari metode Simplex Lattice Design sehingga diperoleh formula optimum. Analisa signifikasi hasil pengujian sifat fisikokimia dan aktifitas antibakteri antar sediaan secara percobaan dan dan teoritis dengan uji $T$ satu sampel, serta signifikasi. Efektifitas sediaan optimum dan kontrol positif dengan uji $\mathrm{T}$ independent. 
HASIL DAN PEMBAHASAN

Simplisia yang digunakan sebanyak 303,08 g yang dilakukan dengan 15 kali penyarian dimana setiap kali penyarian menggunakan simplisia sebanyak 20,00 g dalam $150 \mathrm{~mL}$ etanol $96 \%$. Berat ekstrak yang didapat sebanyak 52,2 g sehingga diperoleh nilai rendemen sebesar $22318 \%$. Hasil uji skrining fitokimia dapat dilihat pada tabel 2, yang menunjukkan bahwa ekstrak etanol rimpang jahe merah memiliki senyawa alkaloid, tannin, fenol, flavonoid dan triterpenoid.

\section{Uji Aktivitas Ekstrak Etanol Rimpang Jahe Merah}

Zona hambat pada konsentrasi 5\%, $10 \%$ dan $20 \%$ sebesar $11 \mathrm{~mm}, 13 \mathrm{~mm}$ dan 7,67 mm, dapat dilihat pada tabel 3 .

Tabel 2 Hasil Uji Skrining Fitokimia Ekstrak Rimpang Jahe Merah

\begin{tabular}{|c|c|c|c|c|c|}
\hline No. & $\begin{array}{l}\text { Skrining } \\
\text { Metabolit }\end{array}$ & Pereaksi & Warna Awal & Perubahan Warna & Hasil \\
\hline 1. & Alkaloid & $\begin{array}{l}\text { Meyer, } \\
\text { Dragendrof }\end{array}$ & $\begin{array}{l}\text { Larutan } \\
\text { bewarna orange }\end{array}$ & $\begin{array}{lr}\begin{array}{l}\text { Terbentuk } \\
\text { orange }\end{array} & \text { endapan } \\
\text { endapan } & \text { (Meyer), } \\
\text { (Dragendrof) } & \text { putih }\end{array}$ & $(+)$ \\
\hline 2. & Fenol & $\mathrm{FeCl}_{3}$ & $\begin{array}{l}\text { Larutan } \\
\text { bewarna orange }\end{array}$ & Biru kehijauan & $(+)$ \\
\hline 3. & Flavonoid & $\begin{array}{l}\text { Serbuk Mg, } \\
\mathrm{HCl}\end{array}$ & $\begin{array}{l}\text { Larutan } \\
\text { bewarna orange }\end{array}$ & $\begin{array}{l}\text { Orange tua agak } \\
\text { kemerahan }\end{array}$ & $(+)$ \\
\hline 4. & Saponin & Aquades & $\begin{array}{l}\text { Larutan } \\
\text { bewarna orange }\end{array}$ & Tidak terbentuk busa & $(-)$ \\
\hline 5. & Triterpenoid & $\begin{array}{l}\mathrm{CH}_{3} \mathrm{COOH} \\
\text { glasial, } \mathrm{H}_{2} \mathrm{SO}_{4} \\
\text { pekat }\end{array}$ & $\begin{array}{l}\text { Larutan } \\
\text { bewarna orange }\end{array}$ & $\begin{array}{l}\text { Terbentuk } \\
\text { merah }\end{array}$ & $(+)$ \\
\hline 6. & Steroid & $\begin{array}{l}\mathrm{CH}_{3} \mathrm{COOH} \\
\text { glasial, } \mathrm{H}_{2} \mathrm{SO}_{4} \\
\text { pekat }\end{array}$ & $\begin{array}{l}\text { Larutan } \\
\text { bewarna orange }\end{array}$ & $\begin{array}{l}\text { Tidak terbentuk } \\
\text { cincin hijau }\end{array}$ & $(-)$ \\
\hline 7. & Tanin & $\mathrm{NaCl}$, Gelatin & $\begin{array}{l}\text { Larutan } \\
\text { bewarna orange }\end{array}$ & $\begin{array}{l}\text { Terbentuk endapan } \\
\text { putih }\end{array}$ & $(+)$ \\
\hline
\end{tabular}

Keterangan : (+) : Positif, ada kandungan senyawa,

$(-)$ : Negatif, tidak ada kandungan senyawa

Tabel 3. Hasil Pengujian Aktivitas Antibakteri Jahe Merah ( $\bar{x} \pm \mathrm{SD}, \mathrm{n}=3$ )

\begin{tabular}{l|c|c|c}
\hline \multirow{2}{*}{ No. } & Konsentrasi ekstrak & \multicolumn{2}{|c}{ Diameter daerah hambatan $(\mathrm{mm})$} \\
\cline { 3 - 4 } & $(\%)$ & S. aureus & S. epidermidis \\
\hline 1. & 5 & $11 \pm 1,4$ & $0 \pm 0$ \\
2. & 10 & $13 \pm 2,16$ & $0 \pm 0$ \\
3. & 20 & $7,67 \pm 1,247$ & $0 \pm 0$ \\
4. & Kontrol (-) & 0 & 0 \\
\hline
\end{tabular}

Keterangan :

SD : Standar Deviasi ;

$\bar{x}$ :rata-rata 
Hasil tersebut telah dilakukan uji signifikansi dengan menggunakan uji Independent T-test dimana pada ketiga konsentrasi menunjukkan data yang tidak berbeda signifikan $(p>0,05)$ sehingga dipilih konsentrasi $5 \%$ sebagai zat aktif pada sabun cair. Hasil uji aktivitas antimikroba dari kontrol negatif menunjukkan tidak terbentuknya zona hambat. Begitu pula pada S.epidermidis yang tidak memiliki zona hambat, hal tersebut diduga terdapat faktor yang dapat mempengaruhi, seperti kecepatan aktivitas antibakteri dari ekstrak ke dalam medium lebih rendah daripada kecepatan pertumbuhan bakteri. Selain itu lokasi pengambilan tanaman rimpang jahe merah juga dapat mempengaruhi banyaknya metabolit sekunder yang dihasilkan (Mishra, 2012), contohnya unsur hara yang terkandung dalam tanah. Sementara itu keberadaan sejumlah logam berat dan pencemar lainnya juga dapat mengubah metabolit sekunder yang ada dalam tanaman. Semakin banyak senyawa yang terkandung dalam tanaman maka efektivitas antibakteri juga meningkat, sehingga ekstrak etanol rimpang jahe merah tidak efektif menghambat pertumbuhan bakteri.

Aktivitas antibakteri ekstrak etanol rimpang jahe merah terhadap bakteri S.aureus ini diduga aktivitas berbagai senyawa yang terkandung dalam ekstrak. Senyawa metabolit sekunder suku Zingiberaceae dapat menghambat pertumbuhan bakteri S.aureus (Nursal, dkk., 2006).

\section{Hasil pengujian sifat fisikokimia}

Metode yang digunakan untuk mendapatkan formula optimum yaitu Simplex Lattice Design (SLD). Rancangan formula SLD terdiri dari 5 formula dengan perbandingan minyak jarak dan $\mathrm{KOH}$ berturut-turut sebesar $0: 100,25: 75,50: 50,75: 25,100: 0$. Hasil uji sifat fisikokimia formula simplex lattice design dapat dilihat pada Tabel 4.

Tabel 4. Hasil Uji Sifat Fisikokimia Formula Simplex Lattice Design (n=3; mean \pm (SD))

\begin{tabular}{ccccc}
\hline & \multicolumn{4}{c}{ Parameter } \\
\cline { 2 - 5 } F & $\mathrm{pH}$ & Viskositas (p) & Asam Lemak Bebas (\%) & Alkali Bebas (\%) \\
\hline F1 & $11,2 \pm 0,16$ & $18,3 \pm 0,47$ & $0 \pm 0$ & $0,33 \pm 0,012$ \\
F2 & $9,13 \pm 0,12$ & $8,3 \pm 0,047$ & $1,73 \pm 0,02$ & $0 \pm 0$ \\
F3 & $8,6 \pm 0,08$ & $7,6 \pm 0,08$ & $1,99 \pm 0,014$ & $0 \pm 0$ \\
F4 & $8,2 \pm 0,16$ & $5,2 \pm 0,08$ & $2,17 \pm 0,028$ & $0 \pm 0$ \\
F5 & $7,9 \pm 0,08$ & $1,03 \pm 0,12$ & $2,42 \pm 0,03$ & $0 \pm 0$ \\
\hline
\end{tabular}

Keterangan :

F: formula,

F1: perbandingan minyak jarak dan $\mathrm{KOH} \mathrm{0:100,}$

F2: perbandingan minyak jarak dan $\mathrm{KOH} 25: 75$,

F3: perbandingan minyak jarak dan $\mathrm{KOH}$ 50:50,

F4: perbandingan minyak jarak dan $\mathrm{KOH} \mathrm{75:25,}$

F5: perbandingan minyak jarak dan $\mathrm{KOH}$ 100:0,

SD: standar deviasi,

mean: rata-rata

\section{Uji pH}

pH merupakan parameter yang sangat penting dalam pembuatan suatu sabun, dimana $\mathrm{pH}$ yang terlalu rendah menyebabkan iritasi kulit sedangkan $\mathrm{pH}$ yang terlalu tinggi menyebabkan kulit bersisik (Wasitaatmadja, 1997). Rentang $\mathrm{pH}$ sediaan sabun berdasrkan Standar 
Nasional Indonesia (SNI) tahun 1996 adalah 8-11. Formula yang mengandung $\mathrm{KOH}$ lebih banyak dibanding minyak jarak memiliki $\mathrm{pH}$ yang lebih besar, hal tersebut dikarenakan gugus basa yang berlebih dan tidak terikat pada komonen lemaknya (Rowe, dkk., 2006). Hubungan antara kedua komponen tersebut dapat dilihat pada gambar 1 .

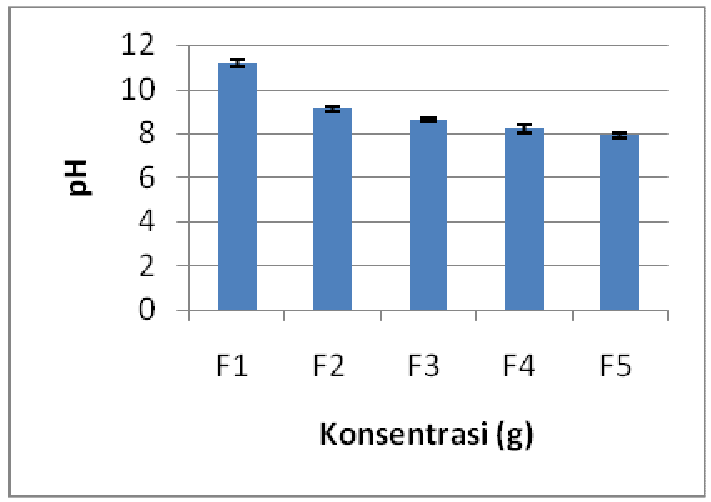

Gambar 1. Hubungan konsentrasi minyak jarak dan $\mathrm{KOH}$ terhadap $\mathrm{pH}$

Berdasarkan hasil uji Anova memiliki nilai $\mathrm{p}<0,05$ dimana nilai tersebut menunjukkan komponen A dan $\mathrm{B}$ berpengaruh signifikan terhadap respon $\mathrm{pH}$. Hasil tersebut dapat dibuktikan dengan persamaan 1 yang dihasilkan dari metode Simplex Lattice Design.

$y=7,98 A+11,35 B-5 A B$

(Persamaan 1)

keterangan :

y $: \mathrm{pH}$

A : minyak jarak

B : $\mathrm{KOH}$

$\mathrm{AB}$ : minyak jarak dan $\mathrm{KOH}$

\section{Uji Viskositas}

Viskositas sediaan berpengaruh terhadap penerimaan dan penentuan wadah yang sesuai. Hasil yang didapatkan bahwa minyak jarak dan $\mathrm{KOH}$ berpengaruh terhadap kekentalan sediaan. Semakin besar konsentrasi $\mathrm{KOH}$ maka semakin besar pula nilai viskositasnya. Hal ini dikarenakan $\mathrm{KOH}$ dapat mengikat fase minyak dan akan membentuk misel (Hawab, 2007). Menurunnya viskositas dikarenakan keberadaan minyak yang terkandung dalam sabun dalam jumlah yang banyak menjadikan sabun menjadi lebih cair. Hubungan dari kedua komonen tersebut data dilihat ada gambar 2 .

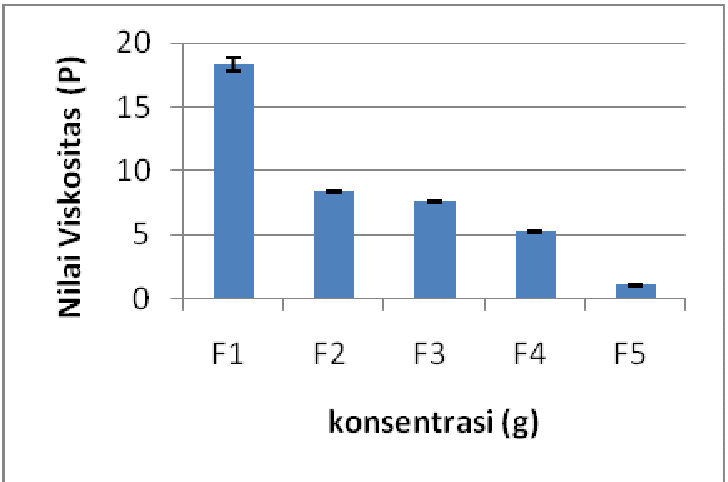

Gambar 2. Hubungan konsentrasi minyak jarak dan $\mathrm{KOH}$ terhadap viskositas

Hasil uji Anova menunjukkan model cubic memiliki nilai $\mathrm{p}<0,05$ sehingga komponen A dan B berpengaruh signifikan terhadap respon viskositas. Hal tersebut data dibuktikan dengan persamaan 2 .

$\mathrm{y}=0,90 \mathrm{~A}+18,20 \mathrm{~B}-19,50 \mathrm{AB}$

(Persamaan 2)

keterangan :

y : viskositas

A : minyak jarak

$\mathrm{B}: \mathrm{KOH}$

$\mathrm{AB}$ : minyak jarak $\mathrm{KOH}$

\section{Uji Asam Lemak Bebas}

Pengujian asam lemak bebas pada sediaan sabun bertujuan untuk menentukan jumlah asam lemak yang tidak tersabunkan. Asam lemak bebas ini berpengaruh terhadap buih yang dihasilkan serta perubahan $\mathrm{pH}$ yang terjadi. Semakin banyak jumlah minyak dibanding $\mathrm{KOH}$ pada sediaan maka jumlah asam lemak bebas juga meningkat. Hubungan kedua komonen tersebut dapat dilihat pada gambar 3 . 


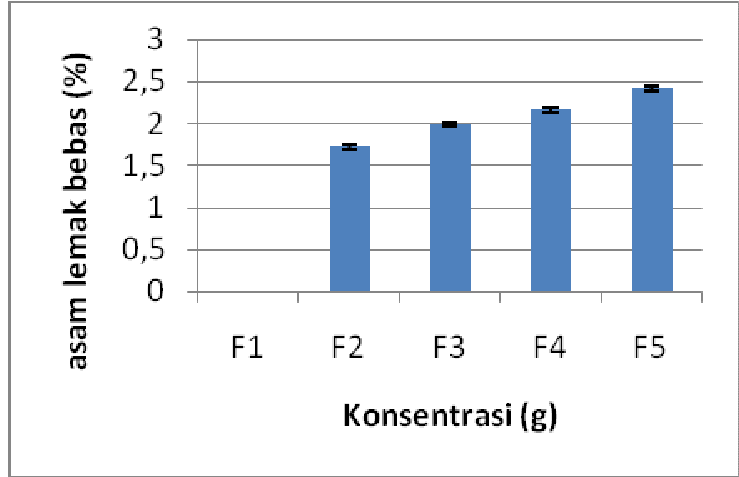

Gambar 3. Hubungan konsentrasi minyak jarak dan $\mathrm{KOH}$ terhadap Asam Lemak Bebas

Hasil uji Anova menunjukkan nilai $\mathrm{p}<0,05$; sehingga dapat diketahui bahwa pengaruh komponen $\mathrm{A}$ dan $\mathrm{B}$ berpengaruh signifikan terhadap respon asam lemak bebas yang terkandung dalam sediaan sabun cair. Hal tersebut dapat dibuktikan dengan persamaan 3, dimana komponen A yang bertanda positif dengan nilai lebih besar dibanding komponen B menunjukkan komponen A dapat meningkatkan nilai asam lemak bebas.

$\mathrm{y}=2,437 \mathrm{~A}+0,017 \mathrm{~B}+3,467 \mathrm{AB}$

(Persamaan 3)

keterangan :

y : respon

A : minyak jarak

$\mathrm{B}: \mathrm{KOH}$

$\mathrm{AB}$ : minyak jarak dan $\mathrm{KOH}$

\section{Uji Alkali Bebas}

Penentuan jumlah alkali bebas ini bertujuan untuk mengetahui jumlah alkali yang tidak berikatan dengan minyak. Jumlah alkali bebas ini berpengaruh terhadap keamanan kulit. Daya alkalinisasi sabun dianggap sebagai faktor terpenting dari efek samping sabun. Hal ini dikarenakan reaksi basa yang terjadi pada sabun dapat menyebabkan iritasi pada kulit (Hawab, 2007). Nilai alkali bebas berbanding lurus dengan nilai $\mathrm{pH}$, dimana semakin banyak $\mathrm{KOH}$ yang terkandung maka semakin meningkat nilai alkali bebas.
Berdasarkan standar SNI, nilai alkali bebas pada sediaan sabun yaitu $<0,1 \%$, sedangkan formula F1 memiliki alkali bebas dengan rata-rata $0,3 \%$ dan tidak memenunhi syarat SNI. Hal tersebut dapat dilihat pada persamaan 4 .

$\mathrm{y}=-4,809 \mathrm{~A}+0,331 \mathrm{~B}-0,769 \mathrm{AB}$

(Persamaan 4)

keterangan :

y : alkali bebas

A : minyak Jarak

B : $\mathrm{KOH}$

$\mathrm{AB}$ : minyak jarak dan $\mathrm{KOH}$

\section{Penentuan formula optimum}

Data hasil pengujian sifat fisikokimia yang telah didapatkan, diolah untuk mendapatkan formula optimum. Komponen yang dioptimasi adalah minyak jarak dan $\mathrm{KOH}$. Formula optimum hasil prediksi terdiri dari 26,69 g minyak jarak dan 7,25 g KOH, dengan nilai desirability 0,732 dapat dilihat pada gambar 4.

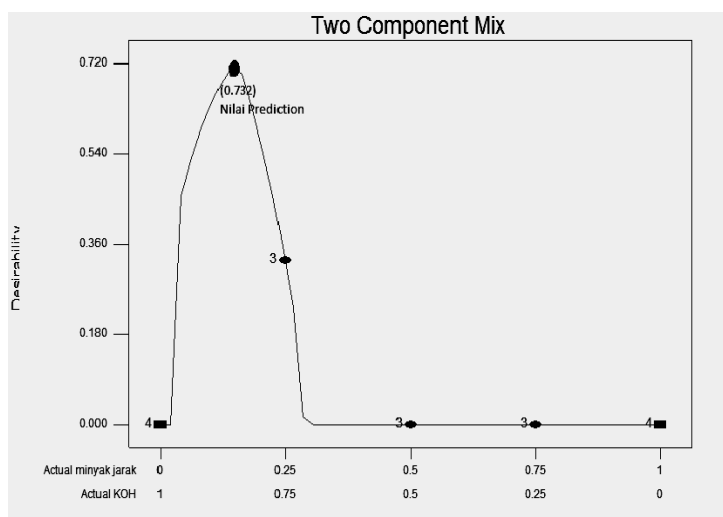

Gambar 4. Kurva desirability

Hasil pengujian sifat fisikokimia formula optimum data dilihat pada tabel 5.

Hasil pengujian sifat fisikokimia dianalisa menggunakan uji Wilcoxson Test. Taraf kepercayaan yang digunakan adalah $95 \%(0,95)$ dan nilai signifikansi $5 \%(0,05)$. Besarnya nilai signifikansi tersebut menyatakan resiko kesalahan yang dapat ditoleransi dalam pengambilan kesimpulan. Apabila nilai signifikansi lebih dari $5 \%$ berarti 
menyatakan adanya perbedaan yang signifikan, begitu pula sebaliknya. Hasil pengujian menunjukkan bahwa nilai $\mathrm{pH}$, vioskositas, asam lemak bebas dengan hasil prediksi program menunjukkan nilai $\mathrm{p}>0,05$, dimana hasil ini menyatakan hasil uji dengan prediksi tidak berbeda signifikan. Akan tetapi nilai alkali bebas dengan hasil prediksi menunjukkan nilai $\mathrm{p}<0,05$ yang berarti bahwa terdapat perbedaan yang signifikan antara hasil prediksi. Nilai alkali bebas yang berbeda signifikan tersebut dapat dibuktikan dengan persamaan 13, dimana nilai respon menunjukkan ketidaksesuaian terhadap nilai prediksi. Persamaan yang ditawarkan oleh Simplex Lattice Design bertujuan untuk menentukan hasil respon tanpa melakukan perlakuan.

\section{Hasil Pengujian Uji Efektivitas Sabun Cair Formula Optimum}

Formula optimum sabun cair ekstrak etanol rimpang jahe merah dengan perbandingan minyak jarak dan $\mathrm{KOH}$ sebesar $15 \%$ dan $85 \%$, dilakukan uji efektivitas terhdap S.aureus dan S.epidermidis. Hasil uji efektivitas antibakteri dapat dilihat pada tabel 6.

Tabel 5. Hasil Pengujian Sifat Fisikokimia Formula Optimum ( $\mathrm{n}=3 ; \bar{x}$ Respon \pm SD)

\begin{tabular}{cccc}
\hline Respon & Hasil Uji & Hasil Prediksi & Nilai Signifikansi \\
\hline $\mathrm{pH}$ & $9,4 \pm 0,14$ & 9.8 & $\mathrm{P}>0,05$ \\
Viskositas (cP) & $1233 \pm 0,47$ & 1168 & $\mathrm{P}>0,05$ \\
Asam Lemak Bebas (\%) & $1,141 \pm 0,025$ & 1.2 & $\mathrm{p}>0,05$ \\
Alkali Bebas (\%) & $0 \pm 0$ & 0,1 & $\mathrm{P}<0,05$ \\
\hline
\end{tabular}

Keterangan :

$$
\begin{aligned}
& \text { SD: standar deviasi, } \\
& \bar{x}: \text { rata-rata }
\end{aligned}
$$

Tabel 6. Hasil Uji Efektivitas Sabun Cair Ekstrak Etanol Rimpang Jahe Merah $(\bar{x} \pm \mathrm{SD}, \mathrm{n}=3)$

\begin{tabular}{c|c|c|c}
\hline \multirow{2}{*}{ No. } & \multirow{2}{*}{ Formula } & \multicolumn{2}{|c}{ Diameter Zona Hambat $(\mathrm{mm})$} \\
\cline { 3 - 4 } & & S. aureus & S. epidermidis \\
\hline 1. & $\mathrm{~A}$ & $13 \pm 2,3$ & $16,82 \pm 1,12$ \\
2. & $\mathrm{~K}-$ & $0 \pm 0$ & $0 \pm 0$ \\
3. & $\mathrm{~K}+$ & $19,67 \pm 2,05$ & $17,26 \pm 0,43$ \\
\hline
\end{tabular}

Keterangan :

$$
\begin{aligned}
& \text { A : Formula Optimum } \\
& \text { K- : Kontrol Negatif (Basis) } \\
& \text { K+ : Kontrol Positif (Dettol) }
\end{aligned}
$$

Tabel 6 menunjukkan diameter zona hambat terhadap bakteri S.aureus dan S.epidermidis yang lebih besar dibanding dengan ekstrak tanpa dibuat sediaan (gambar 5). Hal tersebut diduga adanya bahan tambahan pada sediaan sabun sebagai penghantar yang baik yaitu gliserin dan asam oleat. Gliserin berfungsi sebagai humektan yaitu dapat membantu mempertahankan keberadaan zat aktif dan asam oleat berfungsi sebagai penetrasi (Voigt, 1995). Cara kerja dari asam oleat yaitu dapat meningkatkan difusi zat aktif dengan meningkan aliran ke dalam sel (Verma dan Ram, 2011).

Hasil pengamatan efektivitas antibakteri sediaan optimum pada S.aureus dan S.epidermidis menunjukkan kontrol negatif yang hanya mengandung 
basis tidak memiliki zona hambat (gambar 5 dan 6).

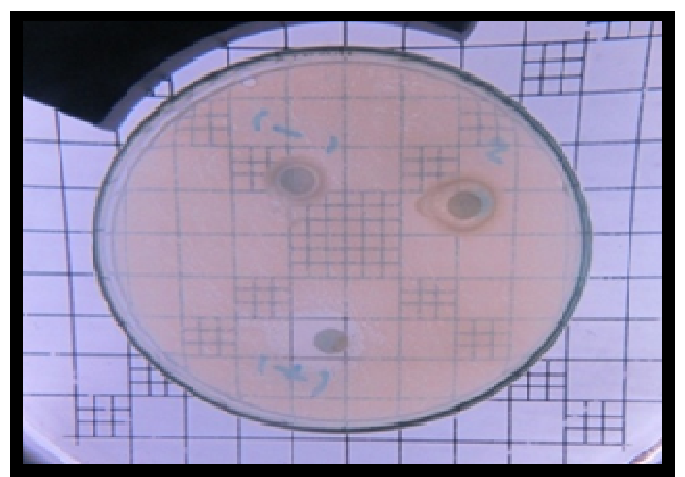

Gambar 5. Zona hambat S.aureus

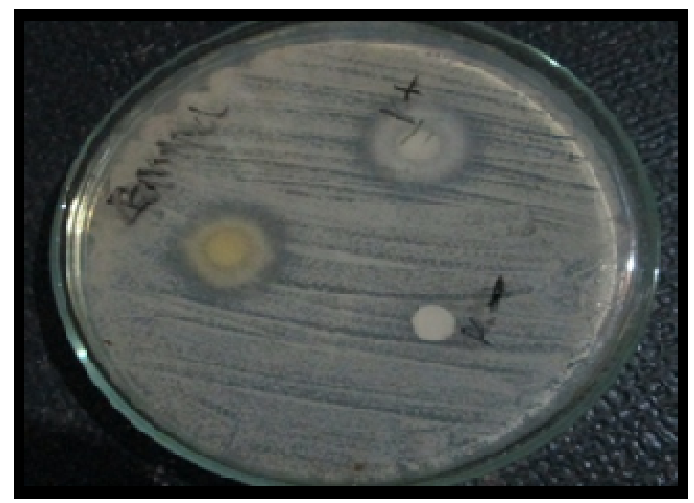

Gambar 6. Zona hambat epidermidis

Hasil pengujian efektivitas sabun cair optimum dan kontrol positif dianalisa menggunakan uji $\mathrm{T}$ Independent. Hasil analisa menunjukkan bahwa efektivitas sabun cair yang optimum terhadap S.aureus memiliki nilai $\mathrm{p}<0,05$ yang artinya berbeda signifikan dengan kontrol positif. Hal ini dapat dikatakan bahwa sabun cair ekstrak etanol rimpang jahe merah optimum yang dihasilkan mempunyai efektivitas yang tidak menyerupai dengan kontrol positif. Berbeda halnya dengan hasil analisa terhadap S.epidermidis yang memiliki nilai $\mathrm{p}>0,05$, yang artinya tidak berbeda signifikan terhadap kontrol positif, sehingga dapat dikatakan sabun cair ekstrak etanol rimpang jahe merah yang optimum mempunyai efektivitas yang menyerupai dengan kontrol positif.

\section{KESIMPULAN}

Berdasarkan penelitian yang telah dilakukan diperoleh komponen minyak jarak dan $\mathrm{KOH}$ yang menghasilkan sabun cair yang optimum adalah 40,035 g dan $10,875 \mathrm{~g}(15: 85)$, mempunyai rata-rata $\mathrm{pH} 9,4$; viskositas $1233 \mathrm{cP}$; asam lemak bebas $1,14 \%$; alkali bebas $0 \%$. Konsentrasi ekstrak etanol rimpang jahe merah sebagai antibakteri adalah 5\% dan memiliki efektivitas antibakteri terhadap S.aureus dan S.epidermidis setelah diformulasikan dalam sediaan sabun cair yang optimum.

\section{DAFTAR PUSTAKA}

1. Dewan Standarisasi Nasional (DSN). SNI 06-4085-1996. 1996. Sabun Mandi. Dewan Standarisasi Nasional. Jakarta. Hal. 2-5.

2. Harbone, JB. 1973 Phytochemical Methods: A guide to modern techniques of plant analysis. $3^{\text {th }}$ Edition. New York: Chapman and Hall. hal 279.

3. Hawab HM. 2007. Dasar-Dasar Biokimia. Penerbit Diadit Media. Jakarta. Hal. 193; 201; 203.

4. Hernani, Bunasor T K, Fitriati. 2010.Formula Sabun Transparan Antijamur dengan Bahan Aktif Ekstrak Lengkuas (Alpinia galanga L. Swartz.). Bul. Littro. 21(2). 192205.

5. Indian Council of Medical Research. 2009. Detection of Antimicrobial Resistance in Common Gram Negative and Gram Positive Bacteria Encountered in Infectious deseasesAn Update. ICMR Bulletin. 39(1-3).

6. Kementrian Kesehatan Republik Indonesia. 2011. Profil Kesehatan Indonesia 2010. Kementrian Kesehatan Republik Indonesia. Jakara. Hal.41-42.

7. Kristanti AN, Aminah NS, Tanjung M, Kurniadi B. 2008. Buku Ajar Fitokimia. Surabaya. University Press. Hal. 56. 
8. Kurniawan D W, Sulaiman T N S. 2009. Teknologi Sediaan Farmasi. Graha Ilmu: Yogyakarta. Hal. 92-93, 97.

9. Malu S P, Obochi G O, Tawo E N, Nyong B.E. 2009. Antibacterial Activity and medicinal Properties of Ginger (Zingiber officinale). Global. J. Pure. Appl. Sci. 15(3).

10. Mishra MK, Anil K, Ashok K. 2012. Pharmacological Acivity of Zingiber officinalle. Int J Pharm Chem Scien. 1(3).

11. Notobroto, Hari B, Soedjadi K, Isa M. 2005. Faktor Sanitasi Lingkungan Yang Berperan Terhadap Prevalensi Penyakit Scabies. Jurnal Kesehatan Lingkungan. 2(1).

12. Nursal, Wulandari S., Wilda J.S. 2006. Bioaktifitas Ekstrak Jahe (Zingiber officinale Roxb.) dalam Menghambat Pertumbuhan Koloni Bakteri Escherichia coli dan Bacillus subtilis. Laboratorium Pendidikan Biologi PMIPA FKIP Universitas Riau. Jurnal Biogenesis. 2(2). 64-66.

13. Okigbo R N, Anugasi C L, Amadi JE, Ukpabi UJ. 2009. Potential inhibitory effect of some African tuberous plant extract on Escherichia coli, Staphylococcus aureus and Candida albicans. Int J Integr Biol.

14. Radji M. 2010. Buku Ajar Mikrobilogi : Panduan Mahasiswa Farmasi dan Kedokteran. Penerbit Buku Kedokteran EGC. Jakarta. Hal. 273, 274, 280, 282, 283.
15. Robinson, T. 1983. The Organic Constituents of Higher Plants Their Chemistry and Interrelationships. 5th Ed. North Amherst: Cordus Press.

16. Rowe RC, Paul JS, Sian C.O. 2006. Handbook of Pharmaceutical Excipients. Fifth Edition. Washington DC: Pharmaceutical Press and American Pharmacist Association. Hal. 301; 494-495; 605; 737-738.

17. Sears. 2001. Pure Radiance. Blackie Academe and Professional. London.

18. Verma P, A Ram. 2011. Effect of Different Penetration Enhancer on Skin Permeation of Drug Using Ethosom Carrier System. J Curr Pharm Res. 5(1). Hal 42-44.

19. Voigt R. 1995. Buku Pelajaran Teknologi Farmasi. Gadjah Mada University Press. Yogyakarta. Hal. 312-319.

20. Wasitaatmadja SM. 1997. Penuntun Ilmu Kosmetik Medik. Jakarta: UI Press. Hal. 98-100.

21. Watkinson C. 2000 Liquid Soap Cleaning Up Share. Inform 11. Champaign: AOCS Press. Hal. 11881195. 